\title{
The Effect of Thoracic Ganglion Extracts of the Endocrine Regulation of Larval Ecdysis in Macrobrachium lamerrii
}

\author{
T. Suguna* \\ Fisheries Research Station, S. V. Veterinary University, \\ West Godavari, Andhra Pradesh, India \\ *Corresponding author
}

A B S T R A C T

\begin{tabular}{l} 
K e y w o r d s \\
$\begin{array}{l}\text { Thoracic ganglion } \\
\text { extracts, Larval } \\
\text { ecdysis }\end{array}$ \\
Article Info \\
$\begin{array}{l}\text { Accepted: } \\
12 \text { October } 2020 \\
\text { Available Online: } \\
10 \text { November } 2020\end{array}$ \\
\hline
\end{tabular}

\section{Introduction}

Molting is the dominant metabolic event in the life cycle of these decapods crustaceans. Somatic growth in crustacean is achieved only through this periodic shedding and reformation of the rigid integument. These decapod crustacean larvae undergo several molts during their larval life.

During molt cycle the crustaceans show many cyclic structural, biochemical and physiological changes resulting in ecdysis. The duration of a molt cycle in species specific and each phase of it in larvae can be measured in hours, days or weeks.
Decapod crustacean larvae undergo a series of molts culminating in metamorphosis. Very little is known of the development of any endocrine system in crustacean larvae and the extent to which their mechanisms are altered during molting and metamorphosis. Various physiological and biochemical activities are under hormonal control which originate from endocrine and neuroendocrine systems. Compared to adults, the crustacean larvae remained unexplored to neuroendorcrinological manipulations. So this piece of work was undertaken to reveal the concealed unique roles displayed by the neuroendocrine center, thoracic ganglion in the endocrine regulation of larval ecdysis in M. lamerrii. 


\section{Materials and Methods}

Berried forms of $M$. lamerrii were procured from Kham river, Aurangabad. Larvae were hatched out by $29-30^{\text {th }}$ day of embryonic development. They were separated into two groups of 20 each, as control and experimental. Each group was maintained in aerated glass beakers containing one liter of dechlorinated water.

Thoracic ganglion were isolated from 20 intermolt adult (mature) M. lamerrii. Their extracts were prepared with a few $\mathrm{ml}$ of distilled water, centrifuged at $2000 \mathrm{rpm}$ for 10 minutes. The supernetant of the extract was added into the experimental beakers. These extracts were added daily right from the day of their hatching upto their post larval stage (15 days old). During the tenure, water was changed daily and fed with freshwater algae. Molting records were noted twice daily and the dead animals if any were removed regularly. On $16^{\text {th }}$ day they were fixed in $1 \%$ formalin. Length was measured from the tip of the rostrum to end of the telson exclusive of telson spines. The weight of the animals was also noted.

The experiment was also carried out with juvenile (immature) stage prawn's (neuroendocrine center) thoracic ganglion extracts. The difference in the neuroendocrine center potentionalities of adult (mature) and juvenile (immature) were noted.

\section{Results and Discussion}

The larvae of $M$. lamerrii molt very frequently upto metamorphosis. After the metamorphic molt the frequency in molting was decreased. The $6^{\text {th }}$ molt was the metamorphic molt in these larvae. The intermolt duration in control animals was 4046 hours, whereas in thoracic ganglion extract added larvae it was 20-24 hours (Table 1).

Table.1 Effect of thoracic ganglion extracts on the intermolt duration of larvae of freshwater prawn, $M$. lamerrii

\begin{tabular}{|c|l|c|}
\hline S. No. & Experimental condition & Intermolt period in hours \\
\hline 1. & Control & $40-46$ \\
\hline 2. & Thoracic ganglion extract & $20-24$ \\
\hline
\end{tabular}

Table.2 Effect of thoracic ganglion extracts from juveniles of $M$. lamerrii on the body length $(\mathrm{mm})$ and body weight $(\mathrm{mg})$ in larvae of $M$. lamerrii

\begin{tabular}{|c|l|c|c|}
\hline S. No. & Experimental condition & Length $(\mathbf{m m})$ & Weight $(\mathbf{m g})$ \\
\hline 1. & Control & 5.3 & $2.5 \pm 0.11$ \\
\hline 2. & Thoracic ganglion extract & 5.9 & $2.65 \pm 0.035$ \\
\hline
\end{tabular}

Table.3 Effect of thoracic ganglion extracts from adults of M. lamerrii on the body length (mm) and body weight (mg) in larvae of $M$. lamerrii

\begin{tabular}{|c|l|c|c|}
\hline S. No. & Experimental condition & Length $(\mathbf{m m})$ & Weight $(\mathbf{m g})$ \\
\hline $\mathbf{1 .}$ & Control & 5.3 & $2.5 \pm 0.11$ \\
\hline $\mathbf{2 .}$ & Thoracic ganglion extract & 6.4 & $2.79 \pm 0.02$ \\
\hline
\end{tabular}


As indicated in Table 2 and 3 the thoracic ganglion extract $(6.4 \mathrm{~mm}$ and $2.79 \pm 0.02 \mathrm{~mm})$ added larvae, exhibited increment in their size and weight from that of control group (5.3 \pm and $2.5 \pm 0.11 \mathrm{mg}$ ).

The results of juvenile neuroendocrine extracts were similar to that of adults. But they were not so significant as that of adult neuroendocrine extracts (Table 2 and 3 ).

It is well known that molting in decapod crustaceans is under the endocrine and neuroendocrine regulations. There are many reports of the presence of a stimulating hormone in central nervous system (brain and thoracic ganglion of crustaceans. Our results are in sharp concurrence with these above investigators statements. The thoracic ganglion extract added larvae exhibited the acceleration in frequency of molting and growth (size and weight) indicating that it is a source of molt (growth) accelerating substances.

In Caridina radaohari, $M$. Kistnensis, Penaeus indicus there are reports of the more number of stainable Neurosecretory cell during intermolt. By premolt stage there was a rise in their number and immediately after post-molt (molt) there was a sudden depletion in the number of cells with stainable neurosecretory material in all three parts of central nervous system. This depletion was observed more in thoracic ganglion than in brain and eyestalk. Such a change was also observed by us during our study of "Neurosecretory system during development and metamorphosis" in these larvae. Before $\left(5^{\text {th }}\right.$ day, III stage) and at metamorphic molting stage $\left(10^{\text {th }}\right.$ day, $\mathrm{IV}^{\text {th }}$ stage $)$, the number of stainable neurosecretory cells were more in all the three neuroendocrine centres. The number of cells and stainable neurosecretory cells were more in thoracic ganglion than in brain and eyestalk. After this metamorphic molt a depletion was seen in number and staining intensity $\left(15^{\text {th }}\right.$ day, post larval stage). This depletion was observed more in thoracic ganglion than in brain and eyestalk. And also the molt acceleration (growth) of thoracic ganglion extracts added animals was higher than that of other neuroendocrine extracts. From this we can draw a conclusion that thoracic ganglion is composed of more potential morphogenetic hormones or more number of morphogenetic hormones.

The results of thoracic ganglion extracts of juveniles were similar to that of the adults. The extract added larvae exhibited the acceleration of molting frequency (growth) thus indicating the presence of an acceleratory hormone or factors in thoracic ganglion.

The results of adult (mature) animals were more significant than that of the juveniles (immature). This is indicating that the neuroendocrine hormone or factors in matured animals are more potential than that of the juveniles (immature). Thus from this piece of work we can draw a conclusion that the thoracic ganglion is composed of stimulatory morphogenetic hormones.

\section{Acknowledgements}

We are thankful to the authorities of ONR, USIF for financial assistance through project.

\section{References}

Anil Kumar, G and Aliyodi, K.G. 1980: Ovarian growth induced by eyestalk ablation during the prebreeding season is not normal in the crab. Peratelphusa hydromous (herbest). Int. J.Inverter, Reprod. 2: 95-105.

Brown, F.A., Jr. 1944: Hormones in the crustacean. Their sources and activities Q. Rev. Biol. 19: 118-143. 
Challa, V.R. 1984. Some aspects of Physiology of molting in freshwater prawn, Macrobrachium kistnesis. PhD. thesis, Marathwada University, Aurangabad.

Costlow, J.D. 1968: Metamorphosis in crustaceans, pp-3-41 in Metamorphosis. A problem in Development Biology W.Etkin and L.I. Gilbert, eds Appleton Century, Croff, New York.

Freeman, J.A. and J.D. Costlow, 1980: The molt cycle and its hormonal control in Rhithropanopeus harriaii larvae. Dev. Bio. 74, 479-485.

Highnam, K.C. and L. Hill, 1979: The comparative endocrinology of the invertebrates, Arnold, London.

Hiroshi Takayanagi, Yoshihiro Yamamoto and Naokuni Takeda, 1986: An ovary stimulating factor in the shrimp, Paratya compressa. The journal of experimental Zoology. 240:203-209.

Mc. Canaughe, J.R. 1985: Nutrition and larval growth crustacean Iddues 2 :
Nagabhushanam, R., P.R. Machale and R. Sarojini, 1998: Presence of ovarian stimulating factors in brain and thoracic ganglia of Macrobrachium kistnesis, J. Zool. Res. 1(1): 17-21.

Passano, L.M. 1960. Molting and its control in the physiology of crustacean, (edited by waterman, T.H.) I-473-536, Academic Press, New York.

Sangvikar, P. 1980: Physiology of molting in freshwater prawn, Caridina rajadhari, Ph.D. thesis, Marathwada University, Aurangabad.

Scudamore, H.H. 1947. The influence of sinus glands upon molting and associated changes in the crayfish, Physiol. Zool. 20: 187-208.

Vijayan, K.K. 1988. Studies on the physiology of molting in the Penaeid prawn, Penaeus indicus. H. Milne Edwards, Ph.D. thesis, Central Marine Fisheries Research Institute, Cochin.

\section{How to cite this article:}

Suguna, T. 2020. The Effect of Thoracic Ganglion Extracts of the Endocrine Regulation of Larval Ecdysis in Macrobrachium lamerrii. Int.J.Curr.Microbiol.App.Sci. 9(11): 1316-1319. doi: https://doi.org/10.20546/ijcmas.2020.911.154 